\title{
TEKNOLOGI PRODUKSI NATA DE COCO BERBAHAN BAKU ORGANIK
}

\author{
[Production Technology of Organic Nata De Coco] \\ Lucia C. Mandey ${ }^{1}{ }^{*}$; Dantje Tarore ${ }^{2}$; Jenny E.A. Kandou ${ }^{1}$ dan Natasia M. Dumais ${ }^{3}$ \\ 1) Fakultas Pertanian Universitas Sam Ratulangi, Program Studi Teknologi Pangan \\ 2) Pascasarjana Universitas Sam Ratulangi Program Studi Entomologi minat Entomologi Kesehatan \\ 3) CV EMKA Indococo Sejahtera \\ Email: mandey.lucia@yahoo.com
}

Diterima 03 Oktober 2020 / Disetujui 28 Desember 2020

\begin{abstract}
Production research technology of nata de coco organic aims to find an alternative nitrogen source model to replace Urea Fertilizer (ZA) to produce quality nata de coco products and to implement this model in the community (UKM NATA de COCO). The benefit of this research is to produce quality nata de coco products and contain a source of fiber (dietary fiber). The quantitative Research Methods (laboratory experiments), with Phase I research carried out trough laboratory test with Treatment $A=10$ liters of coconut water $+50 \mathrm{ml}$ of bean sprouts extract; Treatment $B=10$ liters of coconut water $+50 \mathrm{ml}$ mung bean extract; Treatment $C=$ basic ingredients of coconut water 10 liters + coconut milk $50 \mathrm{ml}$ and Treatment $D=$ basic ingredients of coconut water 10 liters $+Z A$ Food Grade 20 grams + the palm tree sap and treatment $E$ $=$ basic ingredients of coconut water $+Z A$ Non FOod Grade (control). The quality parameters of nata de coco studied were water content, rendemen, crude fiber content, thickness, color and weight of the pellicle. Next Phase II Research: Implementation of Alternative Nitrogen Substituted Urea Fertilizer (ZA) source models in Natural Cellulose Small Business (nata de Coco) in Airmadidi District, North Minahasa Regency. The results of the research: (1). Nitrogen sources are obtained from natural / organic ingredients such as: bean sprouts extract, green bean extract, coconut milk, as an alternative to Urea (ZA) fertilizer which can be used by bacteria Acetobacter xylinum to form natural cellulose pellicles, and a source of Acetobacter xylinum from the sap of the Enau tree. (2). A quality nata de coco product is obtained by providing a model for the use of "Food Grade" $N$ sources in small businesses that produce nata de coco in Airmadidi District, North Minahasa Regency.
\end{abstract}

Keywords: dietary fiber, nata de coco, organic

\begin{abstract}
ABSTRAK
Penelitian Teknologi Produksi Nata De Coco Berbahan Baku Organik bertujuan untuk mendapatkan model sumber nitrogen alternatif pengganti Pupuk Urea (ZA) guna menghasilkan produk nata de coco yang berkualitas serta dapat mengimplementasikan model ini kepada masyarakat (UKM Nata de Coco). Manfaat penelitian ini guna menghasilkan produk nata de coco yang berkualitas dan mengandung sumber serat (dietary fiber). Metode Penelitian secara kuantitatif (eksperimen laboratorium), dengan Penelitian Tahap I dilakukan melalui uji laboratorium dengan Perlakuan $\mathrm{A}=$ bahan dasar air kelapa 10 liter + ekstrak tauge 50 $\mathrm{ml}$; Perlakuan $\mathrm{B}=$ bahan dasar air kelapa 10 liter + ekstrak kacang hijau $50 \mathrm{ml}$; Perlakuan $\mathrm{C}=$ bahan dasar air kelapa 10 liter + santan kelapa $50 \mathrm{ml}$ dan Perlakuan $\mathrm{D}$ = bahan dasar air kelapa 10 liter + ZA Food Grade 20 Gram + Nira Pohon Enau dan Perlakuan E = bahan dasar air kelapa + ZA Non Food Grade (Kontrol).Parameter kualitas nata de coco yang diteliti yaitu: kadar air, rendeman, kadar serat kasar, ketebalan, warna dan berat pelikel. Selanjutnya Penelitian Tahap II: Implementasi model sumber nitrogen alternatif pengganti Pupuk Urea (ZA) pada Usaha Kecil nata de coco di Kecamatan Airmadidi Kabupaten Minahasa Utara. Hasil penelitian yang dihasilkan: (1). Diperoleh Sumber Nitrogen dari bahan alami/organik seperti : ekstrak tauge, ekstrak kacang hijau, santan kelapa, sebagai alternatif pengganti Pupuk Urea (ZA) yang dapat digunakan oleh bakteri Acetobacter xylinum dalam menmbentuk pelikel selulosa alami, dan sumber Acetobacter xylinum dari nira pohon Enau. (2). Diperoleh produk nata de coco yang berkualitas dengan memberikan model penggunaan sumber N "Food Grade" pada Usaha Kecil yang memproduksi nata de coco di Kecamatan Airmadidi Kabupaten Minahasa Utara.
\end{abstract}

Kata kunci: dietary fiber, nata de coco, organik 
Versi Online:

http://www.profood.unram.ac.id/index.php/profood e-ISSN: 2443-3446

\section{PENDAHULUAN}

Teknologi proses produksi nata de coco organik memerlukan bahan dasar air kelapa, terutama air dari buah kelapa matang, yang merupakan salah satu jenis limbah dari pembuatan kopra, minyak kelapa, Virgin Coconut Oil (VCO) dan tepung kelapa. Limbah air kelapa tersebut, sering menimbulkan masalah karena dapat mencemari lingkungan, (Mandey, 2016).

Untuk mengatasi masalah pencemaran lingkungan karena air kelapa dan sekaligus meningkatkan nilai ekonomi dari air kelapa, maka air kelapa ini dapat dimanfaatkan dengan mengolahnya menjadi bermacam-macam produk, salah satunya adalah makanan yang mengandung serat tinggi (dietary fiber) berupa produk nata de coco. Nata de coco adalah produk hasil fermentasi dari bakteri Acetobacter xylinum pada substrat yang mengandung gula membentuk lembaran selulosa nata berupa dietary fiber yang kenyal (Mandey, 2018).

Bahan baku air kelapa dapat diperoleh dalam jumlah besar, karena merupakan limbah cair dari industri tepung kelapa; minyak kelapa, dan kopra. Susunan kimia dietary fiber terutama terdiri dari selulosa yang disintesa oleh bakteri yang menguntungkan (Acetobacter xylinum). Umumnya kadar air dari dietary fiber sekitar

$98 \%$. Produk ini mempunyai tekstur yang agak kenyal dengan konsistensi yang kokoh, tergolong makanan yang berkalori rendah, sehingga cocok digunakan sebagai makanan bagi penderita diabetes (Mandey, 2010., dan Mandey, 2016).

Pemanfaatan limbah cair industri dan home industry kelapa sangat membantu masyarakat dalam memanfaatkan teknologi pembuatan nata de coco, guna meningkatkan pendapatan masyarakat di wilayah perkelapaan seperti di Kecamatan Airmadidi Kabupaten Minahasa Utara Provinsi Sulawesi Utara (Mandey, 1997). Selain itu permintaan nata dari daerah-daerah di Indonesia serta negaranegara lain seperti Singapura, Thailand, Filipina dan Belanda di Sulawesi Utara yang belum banyak dipenuhi menunjukkan bahwa prospek pemasaran nata de coco dimasa yang akan datang sangat cerah, mengingat banyak masyarakat yang mulai mengenal produk makanan berserat ini dan mengkonsumsinya.

Permasalahan yang muncul sejak tahun 2015 pada UKM nata de coco, masih kurang menggunakan sumber nutrient dari bahan organik terutama $\mathrm{N}$ food grade dari bahanbahan organik secara alamiah. Sumber $\mathrm{N}$ food grade ini justru sangat penting dibutuhkan oleh bakteri Acetobacter xylinum dalam membentuk pelikel selulosa alami yang berkualitas. Oleh sebab itu telah dilakukan penelitian teknologi produksi nata de coco berbahan baku organik seperti ekstrak tauge, ekstrak kacang hijau, santan kelapa, dan nira pohon enau.

Tujuan penelitian ini untuk mendapatkan model sumber nitrogen alternatif pengganti Pupuk Urea (ZA) guna menghasilkan produk nata de coco yang berkualitas serta dapat mengimplementasikan model ini kepada masyarakat (UKM nata de coco). Manfaat penelitian ini guna menghasilkan produk nata de coco yang berkualitas dan mengandung sumber serat (dietary fiber).

\section{BAHAN DAN METODE}

Penelitian ini dilaksanakan di UPT Laboratorium Terpadu Universitas Sam Ratulangi Manado dan lokasi UKM nata de coco di Kecamatan Airmadidi serta sampel diambil di Kecamatan Airmadidi Kabupaten Minahasa Utara. Lamanya penelitian kurang lebih 12 bulan, yaitu bulan Januari 2018 sampai dengan bulan Desember 2018.

Bahan yang digunakan adalah air buah kelapa tua berumur $10-11$ bulan, asam asetat glasial $99 \%$, inokulum cair bakteri Acetobacter xylinum, sukrosa, amonium fosfat food grade, Pupuk Urea (ZA) sebagai pembanding, sumber Nitrogen food grade (tauge, kacang hijau, santan kelapa, dan nira Pohon Enau), alkohol 95 \%, sukrosa, akuades, kertas koran, kain penutup nampan/baki plastik, kemasan plastik jenis Polietilen (PE), karet. Peralatan yang digunakan yaitu timbangan analitik, pH meter, Gelas Ukur, Corong, Erlenmeyer, Tabung Reaksi, Oven, 
Versi Online:

http://www.profood.unram.ac.id/index.php/profood e-ISSN: 2443-3446
Pro Food (Jurnal IImu dan Teknologi Pangan)

Vol 6 No. 2 November 2020

ISSN: 2443-1095
Pipet, Kompor, Nampan Plastik, Panci Stainlesstell, Penggaris, Saringan, Loyang, Ember Plastik, Jerigen, Drum Plastik, Keranjang Plastik, Sealer, Pisau Stainles steal, Papan pemotong nata (Telenan), Botol, Stoples, Cawan, Plastik Tupperware, Tabung Gas, dan Blender Phillips.

Penelitian Tahap I: Perlakuan $\mathrm{A}=$ bahan dasar air kelapa 10 liter + Sumber $N$ ekstrak Tauge $50 \mathrm{ml}$., Perlakuan $\mathrm{B}=$ bahan dasar air kelapa 10 liter + Sumber $\mathrm{N}$ dari ekstrak Kacang hijau $50 \mathrm{ml}$; Perlakuan $\mathrm{C}=$ bahan dasar air kelapa 10 liter + Santan Kelapa $50 \mathrm{ml}$; Perlakuan $\mathrm{D}=$ bahan dasar air kelapa 10 liter + ZA Food Grade 20 Gram + Nira Pohon Enau 1 liter dan Perlakuan E = bahan dasar air kelapa 10 liter + ZA non food grade (sebagai Pembanding). Tiap perlakuan menggunakan 3 ulangan.

Parameter kualitas nata de coco yaitu: Kadar Air, Rendemen (AOAC, 1995), Serat kasar (AOAC, 2005), (Wijandy dan Fardiaz, 1985 dalam Mandey, 2016)., Warna (metode Multiple Comparison Different of Analysis (MCFA) dengan menggunakan panelis yang sudah terlatih 3-5 orang., Mandey, 2013) dan Berat Pelikel dari lembaran selulosa nata de coco (Wijandy dan Fardiaz, 1985).

Penelitian Tahap II: Implementasi model sumber Nitrogen "Food Grade"pada perlakuan terbaik sebagai Alternatif Pengganti Pupuk Urea pada Usaha Kecil Nata de Coco di Kecamatan Airmadidi Kabupaten Minahasa Utara.

Prosedur mendapatkan Nata de coco (Mandey, 2016 dengan modifikasi) : mulamula dilakukan pengukuran $\mathrm{pH}$ air kelapa, selanjutnya air kelapa disaring dengan menggunakan kain saring untuk membebaskan dari kotoran. Ke dalam tiap 1 liter air kelapa ditambahkan 10 gram sukrosa dan sumber $\mathrm{N}$ sesuai perlakuan. Larutan tersebut kemudian dipanaskan sampai mendidih. Setelah mendidih, didiamkan beberapa saat, kemudian dilakukan kontrol pH larutan (jika $\mathrm{pH}$ larutan melebihi 4), ditambahkan asam asetat glasial untuk mengatur keasaman pada nilai pH 4 . Selanjutnya ditambahkan inokulum cair (Acetobacter xylinum) sebanyak $10 \%$. dan difermentasi dalam wadah plastik segi 4 dan tertutup dengan kertas koran dan juga kain penutup diatasnya, dengan ukuran sebesar 26 - $26 \times 4 \mathrm{~cm}$ selama 5 hari, 6 hari dan 7 hari fermentasi, sesuai perlakuan. Panen nata de coco ini dipanen selama 5, 6 dan 7 hari, dan diukur pH akhir setelah panen. Kemudian dilakukan pengukuran dan analisis terhadap pelikel nata de coco.

\section{HASIL DAN PEMBAHASAN}

\section{Hasil Eksperimen di Laboratorium 1. Kadar Air}

Hasil uji Kadar Air nata de coco yang dihasilkan dari setiap perlakuan, dapat dilihat pada Tabel 1.

Tabel 1. Hasil Uji Kadar Air Nata de coco Dari setiap Perlakuan

\begin{tabular}{|c|c|}
\hline $\begin{array}{c}\text { Kode } \\
\text { sampel }\end{array}$ & \% Kadar Air \\
\hline A1 & 98,79 \\
\hline A2 & 98,79 \\
\hline A3 & 98,75 \\
\hline B1 & 93,32 \\
\hline B2 & 93,04 \\
\hline B3 & 93,58 \\
\hline C1 & 97,29 \\
\hline C2 & 96,72 \\
\hline C3 & 97,35 \\
\hline D1 & 98,42 \\
\hline D2 & 93,88 \\
\hline D3 & 99,41 \\
\hline E1 & 98,59 \\
\hline E2 & 99,07 \\
\hline E3 & 98,71 \\
\hline
\end{tabular}

Pada Tabel 1 dapat dilihat bahwa hasil uji kadar air nata de coco pada perlakuan $\mathrm{E}$ (perlakuan Bahan Dasar Air Kelapa 10 liter + ZA) memberikan hasil pengujian kadar air yang paling tinggi, yakni sebesar $98,79 \%$ diikuti perlakuan A sebesar 98,77 dengan sumber $\mathrm{N}$ dari ekstrak tauge, serta perlakuan $\mathrm{D}$, 
Versi Online:

http://www.profood.unram.ac.id/index.php/profood e-ISSN: 2443-3446
Pro Food (Jurnal IImu dan Teknologi Pangan) Vol 6 No. 2 November 2020

ISSN: 2443-1095 perlakuan C serta perlakuan B. Tingginya kadar air nata de coco, sesuai dengan penelitian dari Ramdani (2008) sebesar 98,47 \%, juga Mandey, dkk (2016) menuliskan bahwa parameter kadar air yang tinggi dapat mempengaruhi kualitas selulosa nata dengan mempengaruhi tekstur selulosa nata tersebut.

Dalam bahan pangan, air berpengaruh pada kenampakan, tekstur, rasa menentukan kesegaran, dan masa simpan produk pangan. Kandungan air berbagai bahan pangan tidak sama, sehingga kaitannya dengan sifat-sifat tersebut juga berbeda. Air berfungsi sebagai media untuk pertumbuhan bakteri selain juga sebagai pelarut. Kadar air pada nata de coco menentukan tekstur, kekenyalan maupun kenampakan felikal nata yang terbentuk.

\section{Rendemen}

Hasil pengujian Rendemen produk nata de coco pada beberapa perlakuan, dapat dilihat pada Tabel 2 .

Tabel 2. Hasil Pengujian Rendemen Produk Selulosa Nata De Coco Pada Beberapa Perlakuan

\begin{tabular}{|c|c|}
\hline Kode sampel & \% Rendemen \\
\hline A1 & 0,70 \\
\hline A2 & 0,61 \\
\hline A3 & 0,59 \\
\hline B1 & 1,50 \\
\hline B2 & 1,92 \\
\hline B3 & 1,52 \\
\hline C1 & 1,17 \\
\hline C2 & 1,10 \\
\hline C3 & 1,24 \\
\hline D2 & 0,58 \\
\hline D3 & 0,67 \\
\hline E1 & 0,63 \\
\hline E2 & 0,61 \\
\hline E3 & 0,68 \\
\hline
\end{tabular}

Pada Tabel 2 Terlihat bahwa perlakuan B (bahan dasar Air Kelapa 10 liter + Sumber N dari ekstrak Kacang Hijau $50 \mathrm{ml}$.), menghasilkan rendemen produk selulosa Nata de coco yang paling tinggi, yakni sebesar $1,65 \%$, diikuti dengan perlakuan $\mathrm{C}$, perlakuan
D, perlakuan E dan perlakuan A. Rendemen nata de coco dapat diketahui berdasarkan perbandingan antara bobot nata de coco dengan bobot medium. Hal ini menunjukkan bahwa banyaknya nata de coco yang terbentuk/dihasilkan, sejalan dengan tingginya rendemen nata de coco. Hal ini sejalan pendapat Alwi, et., al., 2011 dalam eprints.undip.ac.id bahwa, air kelapa akan merubah menjadi selulosa ekstraseluler atau nata selama fermentasi. Rendemen dipengaruhi oleh berbagai hal antara lain keragaman substrat, komposisi bahan, kondisi lingkungan, dan kemampuan Acetobacter xylinum dalam menghasilkan selulosa (Putriana dan Aminah, 2013). Begitu juga dengan pendapat dari Iryandi et. al, 2014 menuliskan bahwa perbandingan nutrisi yang seimbang disertai dengan waktu fermentasi yang cukup akan mendorong Acetobacter xylinum untuk memproduksi benang-benang selulosa pembentuk nata secara optimal sehingga rendemen nata akan semakin tinggi.

\section{Serat Kasar}

Hasil pengujian serat kasar produk nata de coco pada beberapa perlakuan, dapat dilihat pada Tabel 3.

Tabel 3. Hasil Pengujian Serat Kasar Produk Nata de coco Organik Pada Beberapa Perlakuan

\begin{tabular}{|c|c|}
\hline Kode sampel & \% Serat kasar \\
\hline A1 & 35,42 \\
\hline A2 & 43,87 \\
\hline A3 & 39,94 \\
\hline B1 & 61,57 \\
\hline B2 & 61,94 \\
\hline B3 & 61,71 \\
\hline C1 & 44,91 \\
\hline C2 & 45,23 \\
\hline C3 & 45,07 \\
\hline D1 & 42,50 \\
\hline D2 & 43,10 \\
\hline D3 & 41,91 \\
\hline E1 & 42,41 \\
\hline E2 & 41,68 \\
\hline E3 & 37,64 \\
\hline
\end{tabular}


Pada Tabel 3 terlihat bahwa perlakuan B (bahan dasar air kelapa 10 liter + Sumber $\mathrm{N}$ dari ekstrak Kacang Hijau 50 ml.), menghasilkan serat kasar produk nata de coco paling tinggi diantara perlakuan yakni sebesar 61,741 \%, diikuti dengan Perlakuan C, Perlakuan D, Perlakuan E dan Perlakuan A. Analisis kadar serat kasar pada produk nata de coco bertujuan untuk mengetahui kandungan Selulosa sebagai sumber dietary fiber yang dihasilkan oleh Acetobacter xylinum selama proses fermentasi.

Tingginya kandungan serat pada produk nata de coco ini sangat baik bagi kesehatan. Menurut Cho \& Almeida, 2012 beberapa manfaat nata yang telah diketahui adalah mengurangi resiko diabetes, obesitas, penyakit kardiovaskular dan diverticulitis. Nata de coco diketahui juga mampu menurunkan kolesterol. Penelitian Chau et al. (2008) menunjukkan bahwa terdapat penurunan signfikan pada serum trigliserida, serum kolesterol total, dan kolesterol liver. Pada Gambar 1 memperlihatkan contoh serat kasar produk nata de coco.
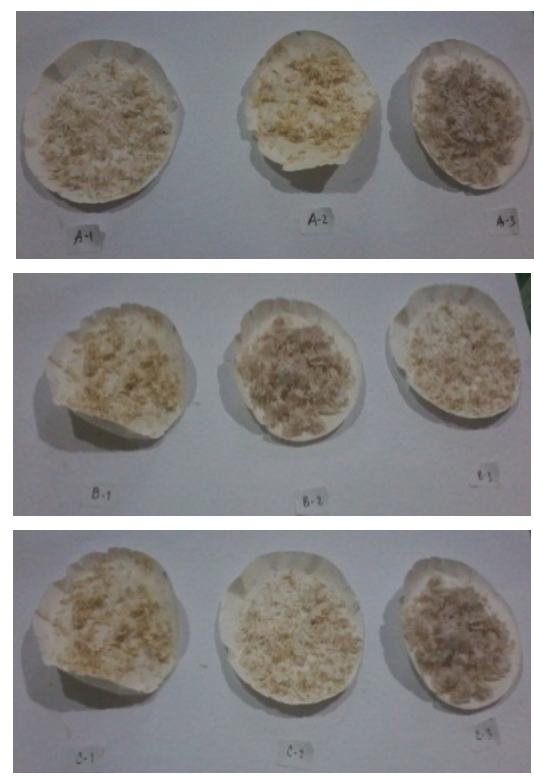

Gambar 1. Contoh Serat Kasar Produk Nata de coco

\section{Ketebalan Nata}

Hasil pengujian ketebalan produk nata de coco pada beberapa perlakuan, dapat dilihat pada Tabel 4.
Tabel 4. Hasil Pengujian Ketebalan Produk Nata de coco Pada Beberapa Perlakuan

\begin{tabular}{|c|c|c|c|}
\hline $\begin{array}{c}\text { Kode } \\
\text { Sampel }\end{array}$ & $\begin{array}{c}\text { Tinggi } \\
\text { Ketebalan } \\
\text { Nata (cm) } \\
\mathbf{0} \text { hari }\end{array}$ & $\begin{array}{c}\text { Tinggi } \\
\text { Ketebalan } \\
\text { Nata } \mathbf{( c m}) \\
\mathbf{5}\end{array}$ & $\begin{array}{c}\text { Tinggi } \\
\text { Ketebalan } \\
\text { Nata (cm) } \\
\mathbf{7 ~ h a r i ~}\end{array}$ \\
\hline A1 & 0 & 1,51 & 1,52 \\
A2 & 0 & 1,53 & 1,54 \\
A3 & 0 & 1,52 & 1,52 \\
B1 & 0 & 1,48 & 1,49 \\
B2 & 0 & 1,47 & 1,48 \\
B3 & 0 & 1,42 & 1,44 \\
& & & \\
C1 & 0 & 1,53 & 1,54 \\
C2 & 0 & 1,56 & 1,57 \\
C3 & 0 & 1,58 & 1,57 \\
& & & \\
D1 & 0 & 1,36 & 1,38 \\
D2 & 0 & 1,32 & 1,33 \\
D3 & 0 & 1,30 & 1,31 \\
& & & \\
E1 & 0 & 1,46 & 1,47 \\
E2 & 0 & 1,38 & 1,39 \\
E3 & 0 & 1,40 & 1,42 \\
& & & \\
\end{tabular}

Pada Tabel 4 terlihat bahwa perlakuan C (bahan dasar Air Kelapa 10 liter + Sumber $\mathrm{N}$ dari Santan Kelapa $50 \mathrm{ml}$ ), pada hari ke 5 waktu panen, menghasilkan ketebalan produk nata de coco paling tinggi diantara perlakuan lainnya yakni sebesar $1,55 \mathrm{~cm}$., diikutidengan Perlakuan A, Perlakuan B, Perlakuan D dan Perlakuan E. Selanjutnya pada waktu panen pada hari ke 7, analisis ketebalan produk Nata de coco yang paling tinggi, yakni pada Perlakuan $C$ dengan tinggi ketebalan nata de coco sebesar $1,56 \mathrm{Cm}$. Analisis ketebalan nata de coco dilakukan pada hasil fermentasi air kelapa menjadi nata de coco. Ketebalan nata diduga sangat didukung oleh mekanisme pembengkakan serat kasar sebagai akibat dari proses pengikatan dan pemerangkapan air dalam matrik serat tersebut. Selama terjadi penebalan lapisan nata de coco, maka ronggarongga yang terdapat dalam nata de coco akan terisi oleh air sehingga nata de coco menjadi tebal. 
Versi Online:

http://www.profood.unram.ac.id/index.php/profood e-ISSN: 2443-3446

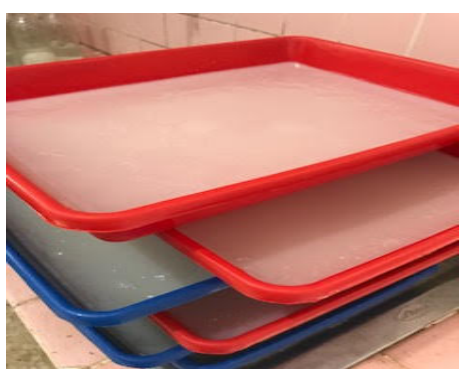

Gambar 2. Nata de Coco Organik yang dihasilkan

\section{Warna}

Hasil pengujian warna produk nata de coco, pada beberapa perlakuan, dapat dilihat pada Tabel 5.

Tabel 5. Hasil Pengujian Warna Produk Nata de Coco Pada Beberapa Perlakuan,

\begin{tabular}{|c|c|c|c|}
\hline $\begin{array}{c}\text { Kode } \\
\text { Sampel }\end{array}$ & $\begin{array}{c}\text { Putih } \\
\text { Susu } \\
\text { (1) }\end{array}$ & $\begin{array}{c}\text { Putih } \\
\text { Kekuningan } \\
\text { (2) }\end{array}$ & $\begin{array}{c}\text { Putih } \\
\text { Keabuan } \\
\text { (3) }\end{array}$ \\
\hline A1 & & $v$ & \\
A2 & & $v$ & \\
A3 & & $v$ & \\
B1 & & $v$ & \\
B2 & & $v$ & \\
B3 & & $v$ & \\
C1 & $v$ & & \\
C2 & V & & \\
C3 & V & & \\
D1 & & & \\
D2 & & & \\
D3 & & & \\
E1 & $\mathrm{V}$ & & \\
E2 & $\mathrm{V}$ & & \\
E3 & $\mathrm{v}$ & & \\
& & & \\
\end{tabular}

Pada Tabel 5 terlihat bahwa, produk nata de coco berwarna putih kekuningan yakni pada Perlakuan A dan Perlakuan B. Sedangkan Perlakuan $C$ dan $E$ berwarna putih susu. dan Perlakuan D berwarna putih keabuan.

Warna produk nata de coco yang dihasilkan sebagian besar berwarna putih susu dan putih keabuan. Warna nata de coco dapat diperbaiki dengan mempercepat waktu fermentasi, karena waktu fermentasi yang semakin lama warna nata menjadi lebih gelap. Hal ini sesuai dengan hasil penelitian Ratnawati (2007), menunjukkan bahwa kualitas terbaik nata de citrus dihasilkan pada $\mathrm{pH} \mathrm{5,0} \mathrm{dan}$ kadar glukosa $78 \mathrm{mg} / 100 \mathrm{ml}$, dengan tebal nata $6,5 \mathrm{~mm}$, berat $10,48 \mathrm{~g}$, rendemen selulosa 2,53 \% dan berwarna putih bersih. Selanjutnya penelitian Rizal, dkk (2013) menunjukkan bahwa kondisi optimum untuk pembentukan nata de Corn adalah pada massa gula sebanyak 9 gram, pH 5 dan waktu fermentasi 14 hari.

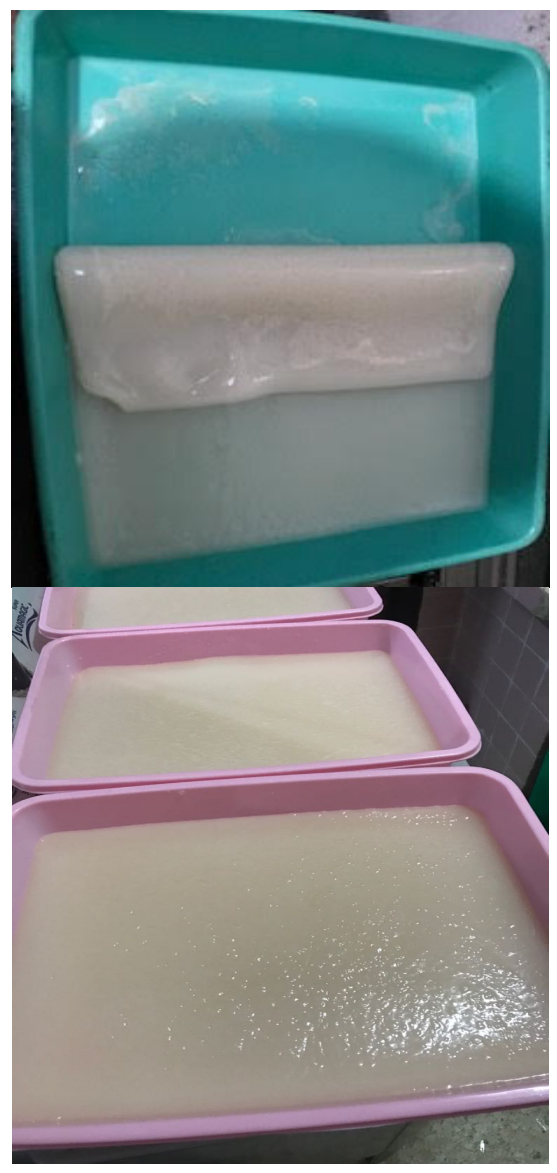

Gambar 4. Warna Produk Nata de coco yang dihasilkan (Sumber UKM Monic Nata De Coco)

\section{Berat Pelikel}

Hasil pengujian Berat Pelikel produk nata de coco, pada beberapa perlakuan, dapat dilihat pada Tabel 6 . 
Versi Online:

http://www.profood.unram.ac.id/index.php/profood e-ISSN: 2443-3446
Pro Food (Jurnal IImu dan Teknologi Pangan)

Vol 6 No. 2 November 2020

ISSN: 2443-1095
Tabel 6. Hasil Pengujian Berat Pelikel Produk Nata de coco Pada Beberapa Perlakuan

\begin{tabular}{|c|c|c|c|}
\hline $\begin{array}{c}\text { Kode } \\
\text { Sampel }\end{array}$ & $\begin{array}{c}\text { Hari } \\
\text { Ke 5 } \\
\text { (gr) }\end{array}$ & $\begin{array}{c}\text { Hari } \\
\text { Ke 6 } \\
\text { (gr) }\end{array}$ & $\begin{array}{c}\text { Hari } \\
\text { Ke 7 } \\
\text { (gr) }\end{array}$ \\
\hline A1 & 740 & 742 & 728 \\
A2 & 752 & 750 & 748 \\
A3 & 747 & 732 & 726 \\
& & & \\
B1 & 714 & 720 & 718 \\
B2 & 696 & 703 & 694 \\
B3 & 690 & 691 & 690 \\
& & & \\
C1 & 856 & 858 & 856 \\
C2 & 858 & 856 & 850 \\
C3 & 850 & 854 & 856 \\
& & & \\
D1 & 532 & 522 & 518 \\
D2 & 540 & 539 & 527 \\
D3 & 502 & 501 & 496 \\
& & & \\
E1 & 840 & 840 & 826 \\
E2 & 842 & 845 & 848 \\
E3 & 840 & 845 & 846 \\
& & & \\
\hline
\end{tabular}

Berat pelikel nata de coco pada beberapa perlakuan dan beberapa waktu pemanenan, menunjukkan hasil yang berbeda-beda, seperti ditujukkan dalam Tabel 6 di atas. Berat pelikel nata tertinggi pada pengamatan/ pemanenan hari ke 5, hari ke 6 dan ke hari ke 7, yakni pada perlakuan $\mathrm{C}$ (dengan sumber $\mathrm{N}$ menggunakan santan kelapa). Beratnya pelikel nata tersebut disebabkan karena adanya beberapa faktor yang mempengaruhi, antara lain : nutrisi yang terkandung di dalam air kelapa dan bahan tambahan lainnya seperti su mber karbon dari sukrosa yang digunaka dan sumber nitrogen dari bahan-bahan alamiah secara organik yang digunakan dalam perlakuan pada penelitian ini seperti tauge, kacang hijau, santan kelapa), nira Pohon Enau, Hal ini sesuai dengan pendapat Nurdyansyah, dkk (2017) bahwa A.xylinum dalam menghasilkan nata dipengaruhi oleh kandungan glukosa dalam substrat atau media yang digunakan. Begitu juga faktor suhu inkubasi, mempengatuhi pertumbuhan A.xylinum. Umumnya suhu optimal yang dibutuhkan dalam pembentukan nata berkisar antara suhu $28-32^{\circ} \mathrm{C}$. Begitu juga dengan tingkat keasaman $(\mathrm{pH})$ dapat mempengaruhi ketabalan nata yang dihasilkan, pada umumnya kondisi keasaman $\mathrm{pH}$ optimal 3,54.

\section{KESIMPULAN}

Hasil penelitian ini, dapat disimpulkan bahwa Sumber Nitrogen dari bahan alam/organik seperti: ekstrak tauge, ekstrak Kacang hijau, santan kelapa, dan nira dari pohon enau sebagai alternatif Pengganti Pupuk ZA, dapat digunakan oleh bakteri Acetobacter xylinum dalam menmbentuk pelikel nata de coco.

\section{DAFTAR PUSTAKA}

Chau, C., Yang P., Yu C., \& Yen G. 2008. Investigation on the Lipid and cholesterol lowering abilities of biocellulose. Journal of Agricultural and Food Chemistry, 56 (6): 2991-2295.

Cho, S., \& Almeida, N. 2012. Dietary fiber and Health. CRC Press.

Mandey, L.C. 1997. Pengolahan Limbah Cair Industri tepung kelapa Secara Fisik, Kimia dan Biologi (Disertasi). Program Pascasarjana Unair, Surabaya.

Mandey, L.C. 2010. Teknologi Pengolahan Kelapa dan Palma Lainnya. Buku Ajar, Program Studi Ilmu dan Teknologi Pangan Jurusan Teknologi Pertanian Fakultas Pertanian Universitas Sam Ratulangi Manado.

Mandey, L.C. 2016. Teknologi Kelapa dan Palma Lainnya. Buku Teks, berISBN. Penerbit Pascasarjana Press Universitas Sam Ratulangi Manado.

Mandey, L.C., J.E.A. Kandou., dan T.M. Langi., 2016. Pengembangan Produksi Selulosa Nata Sebagai Produk Kesehatan Dari Limbah Air Kelapa Dengan Menggunakan Bakteri Acetobacter xylinum. Jurnal IImu dan Teknologi Pangan, Vol. No. 2. 
Nurdyansyah, F., D.A. Widyastuti. 2017. Pengolahan Limbah Air Kelapa Menjadi Nata De Coco Oleh Ibu Kelompok Tani di Kabupaten Kudus. JKB 21(X1).

Peraturan Kepala Badan Pengawas Obat dan Makanan Republik Indonesia Nomor HK.03.1.23.04.12.2206 Tahun 2012 tentang Produksi Pangan yang Baik Untuk Industri Rumah Tangga.

Ratnawati, D. 2007. Kajian Variasi Kadar Glukosa dan Derajat Keasaman (pH) Pada Pembuatan Nata de Citrus dari Jeruk Asam (Citrus limun. L). Jurnal Gradien, 3(2).

Rizal, H. M., D.M. Pandiangan dan A. Saleh., 2013. Pengaruh Penambahan Gula, Asam Asetat dan Waktu Fermentasi Terhadap Kualitas Nata de Corn. Jurnal Teknik Kimia, 1(19).

Rosario, R.D. 1982. Composition and Utilization of Coconut Water. Philipines Coconut Research and Development Foundation. Los Banos. Philipina.

Wong, D.W.S. 1989. Mechanism and Theory in Food Chemistry. Van Nostrand Reinhold. New York. 